\title{
THE CODE OF GOOD AGRICULTURAL PRACTICE AS AN ELEMENT OF SUSTAINABLE DEVELOPMENT BASED ON OPINIONS OF FARM OWNERS
}

\author{
Aeksandra Plonka ${ }^{1}, \mathrm{PhD}$ Eng.; Izabela Wielewska ${ }^{2}, \mathrm{PhD}$ \\ ${ }^{1}$ The University of Agriculture in Krakow, Poland, \\ ${ }^{2}$ UTP University of Science and Technology in Bydgoszcz, Poland
}

\begin{abstract}
The paper discusses the relation between issues related to environment protection and agricultural production. In the first half of 2017, surveys were conducted on 223 farms of which a fragment has been presented showing agricultural producers' opinions about issues related to the Code of Good Agricultural Practice. One of underlying assumptions was an attempt to identify farmers' attitudes to and their opinions about the practical application of principles adopted in the Code and its impact on the implementation of assumptions of the concept of sustainable development. Based on the research, nearly $60 \%$ of respondents had applied the good agricultural practices on their farms. In their opinion, the application of the Code's recommendations helped improve the overall condition of the environment thanks to, among other things, soil protection, landscaping, improved water quality or pollution control. Moreover, the respondents indicated benefits which had direct effect on the functioning and condition of the farm as a unit that helped it stand out among neighbouring farms. One of major obstacles preventing the implementation of good agricultural practices by farms was the lack of information about the Code and promotion of its importance to the implementation of the concept of sustainable development.
\end{abstract}

Key words: the Code of Good Agricultural Practice, agricultural practice, farms, sustainable development, sustainable agriculture.

JEL code: Q56

\section{Introduction}

A few hundred thousand years ago man was a part of the environment participating in a natural energy and matter cycle without interfering with those processes. Unfortunately, as civilization advanced, man's attitude towards appropriated nature has become increasingly disrespectful and strengthened. The industrial revolution and newer and newer inventions diametrically changed the relations between man and the environment. Human activities have caused considerable nuisance to the environment including pollution and damage (Adamska H., 2015). The environment's quality has become a major problem related to man's existence and further civilization advancement (Brown L. et al., 1995; Stacewicz J., 2001; Kozlowski S., 2005; Sadowski A., 2007; Rogall H. 2010; Dacko M., Plonka A., 2012; Adamska H., 2015).

Due to increasing environmental problems, back in the 1960 s measures were taken to improve the environment's condition and protection. Upon the presentation of a list of dangers threatening humans, calls were made to accept challenges in the area of proper development both as regards the present and the future. A potential remedy to solve the problems was the implementation of the concept of sustainable development leading to improved life quality with basic proenvironmental attitudes (Zylicz T., 2004; Wielewska I., 2014; Dacko M., Plonka A. 2017). Adopting such paradigm, it was decided that only such a direction of development respected by all countries in the world may help satisfy the needs of current and future generations (Adamska H., 2015).

The implementation of the concept of sustainable development was started seeking a balance between the environmental, economic and social zone being provided for in a number of legal regulations governing the protection and management of environmental resources. In particular, special attention was paid to the issues of the development of rural areas and agriculture. For ages, being one of strategic sectors of economy, agriculture has had major effect on generating and maintaining diverse habitats, including natural and semi-natural ones characterized by natural richness (Plonka A., 2017). Developing rural areas, starting with plot development and 
management and ending with the entire spatial country layouts, it guarantees consistency between local community and nature that affects and sets the pace of life for its inhabitants (Kozlowski S., 2004). However, on the other hand, intensive changes in farming practices and tillage resulted in significant deterioration of soil condition and the environment's natural quality. Based on the OECD's report (2012), farming is one major factors resulting in the degradation of the environment and the loss of biodiversity. Such hazards are caused by, among other things, land melioration, pollution of soil and water due to excessive chemicalization of agriculture or the introduction of biogeographically alien species into the environment (Krol M. A., 2013). According to Symonides (2008), the more intense agricultural use, the bigger and more long-lasting impact. Hence, from among the systems of modern agriculture, a system that fails to take into account the principles of reasonable use of natural environment is a severe threat (Plonka A., 2017).

For many years the European Union has been promoting the model of agriculture orientated towards pro-ecological measures that respects the principles of sustainable development. Such approach was reflected in the Common Agricultural Policy whereby the application of agricultural practices is required that do not interfere with environmental balance, ensure economic benefits and facilitate social development (Zegar J., 2012). Farmers adjust their agricultural production mostly to meet the criteria of microeconomic effectiveness in that way jeopardizing ecological balance and making the entire society suffer the related costs of reducing the imbalance (Boltromiuk A., 2006). Hence, Mac Sharry's reform introduced the regionalization of agricultural policy, supporting the production methods facilitating the protection of the natural environment and rural areas as well as many forms of excluding land from agricultural production. One of key measures taken to protect the environment included connecting direct payments with the duty of compliance with the rules of the-so-called good agricultural practice and quality standards by farmers which are consistent with the concept of the model of agriculture based on the production that is safe for the environment and consumers' health (Kraciuk J, 2004). Shaping the criteria of granting financial assistance to farmers in that way, they are encouraged to voluntarily increase their ecological awareness as part of environment protection as well as carrying out production on farms in accordance with the adopted principles of good agricultural practice.

\section{Material and the research method}

Connecting the issue of financing farming with the necessity of complying with specific rules of conduct in line with the concept of sustainable agriculture (and development) resulted in a duty imposed on the European Union Member States to develop a document providing for key principles of running a farm. In Poland the Code of Good Agricultural Practice (CGAP)/Kodeks Dobrej Praktyki Rolniczej (KDPR) was developed in 2004 and its provisions detail agricultural practices that were favourable to the environment and contain information being the source of expertise regarding the protection of its individual elements. The Code is a source of information about what is permitted or prohibited in agricultural activities and helps prevent violations. Hence, it is the collection of practices that helps shape farmers' social attitude vis-a-vis the applicable law, teaching them how to minimize the adverse impact on the environment (Kania J., 2006).

The Code in a detailed manner explains the principles (good practices) which in particular refer to (Kania J., 2006): 
- arranging and managing a sustainable farm (managing the layout of land, the organization of plant and animal production, the balance of minerals and organic substances, the integrated plant protection);

- protecting water against pollution from point and area sources (the use of panels with containers to store manure, the dosage and time limits for the use of manure and mineral fertilizers, the use of sewage and sludge, the application of chemical plant protection agents, agritechnical water pollution methods),

- protecting agricultural land, in particular, against erosion and physical degradation (water and wind erosion, soil air/water ratio on green wastelands and arable land), chemical degradation (the contents of assimilable nutrients, soil $\mathrm{pH}$ ) and biological degradation (organic soil substances and soil's biological activity),

- protecting the air (pollution and exhaust gas level, odour substances, ammonia, greenhouse gases),

- protecting the landscape and maintaining biodiversity (farmsteads as a part of landscape, biodiversity on farms).

However, the farmers who are not beneficiaries of the system of direct payments or other Common Agricultural Policy programs are not obligatorily required to comply with the principles and recommendations of the Code of Good Agricultural Practice. Thus, their implementation in practice mostly depends on a given farmer's level of expertise, including their awareness of the impact of their agricultural activity (especially the adopted agricultural system) on the environment and their so-called good will which frequently reflects that they are aware of the related benefits (Plonka A., 2017).

In this paper, a fragment of the research conducted in 2017 is presented that involved farms located in Poland and engaged in diverse agricultural production. The main reason for the research was to show the attitude of agricultural producers to issues related to the CGAP. The main research aim was an attempt at identifying farmers' attitudes to and their opinions about the practical application of principles adopted in the Code and its impact on the implementation of assumptions of the concept of sustainable development.

In the survey, 223 farm owners participated, including 127 engaged in plant production, 33 specializing in animal production and 63 applying a mixed system (i.e. plant and animal production). The criterion for the selection of research subjects was engagement in activities adjusted to local natural conditions that reflect the most popular field system and/or animal production system representing diverse directions and production intensity. At the same time, as part of the research it was assumed that farms may be run by semi-agricultural farmers.

The main research tool employed to gather information and empirical data was a questionnaire with a categorized set of questions divided into five basic sections. Answering questions in the questionnaire the respondents, among other things, assessed their knowledge of the Code's principles, described the impact of the Code's recommendations on the organization of farm labour, indicated noticeable benefits stemming from their practical application and referred to the impact of the CAGP on the implementation of the assumptions underlying the concept of sustainable development. Due to limitations of this paper, only a small portion of the research results is presented, i.e. those that refer to the issue of the respondents' life in compliance with the CAGP and sustainable development. 
The survey was conducted using two research techniques. The first was a random survey whereby the questionnaires were handed over to the respondents and filled out by people gathered in a given space. Computer Assisted Web Interviews (CAWI) was another technique helpful with data collection. Currently, it is one of the most frequently used research techniques as part of which questionnaires are sent by electronic mail and completed online by respondents (Sobocinska, 2005). Therefore, since the survey is partially completed in an electronic format, a hyperlink to the questionnaire embedded on a Google drive was made available to the respondents.

\section{Research results and discussion}

The Code of Good Agricultural Practice's primary goal is to propagate knowledge of the protection of individual elements of the natural environment among farmers, such as soil, water, air and landscape. In line with the CGAP, the pursuit of the goals of both sustainable agriculture and sustainable development is interrelated to farmers' great ecological awareness. In particular, special attention should be paid to intensions of farm owners in the context of their responsibility for the condition of the environment in rural areas. Raising the farmers' ecological awareness has an effect on the form and quality of their agricultural business. On farms where recommendations and advice provided by the code are followed, there is hardly any risk of the agricultural production's adverse effect on the quality and state of resources of the natural environment or such risk is minimized (Plonka A., 2017).

Taking into account that fact that the Code of Good Agricultural Practices is embedded in legal regulations, it could be reasonably expected that the document itself and its contents should be commonly known. More than $25 \%$ of the owners of farms taking part in the survey stated the opposite and stressed that they have not come across the concept of the Code or its contents until the survey (Figure 1). Nearly $75 \%$ of the respondents confirmed that they were familiar with the concept of the CGAP whereas the evaluations of their knowledge of the Code's contents were diversified. The respondents mostly rated their knowledge of the contents of the CGAP as basic ( $32 \%$ ) or average ( $24 \%$ ). Every fourth respondent stated that they were not familiar with the concept of the CGAP or its recommendations.

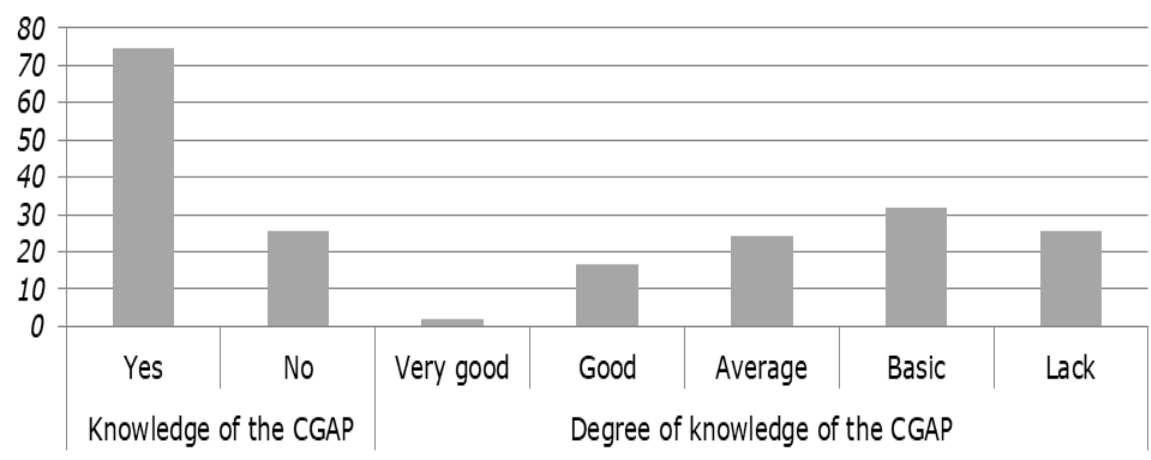

Source: author's calculations based on research and Plonka 2017

Fig. 1. Knowledge of the concept and principles of the CGAP based on the farmers' opinions (in \%)

In the further part of the survey, the farm owners who were familiar with the concept of the Code (i.e. 167 respondents), were enquired about the practical application of its guidelines. Only $12 \%$ of the respondents admitted that they had followed the Code's practices and recommendations in a comprehensive manner. On the other hand, $47 \%$ of the respondents 
admitted that they had been practicing them on their farms but only partially, that is, followed selected recommendations only. Among a broad range of reasons that resulted in a relatively high percentage of negative answers that indicated that the Code's recommendations have not been followed in practice, the respondents indicated, among other things, the lack of the related information as one of reasons for such situation (Figure 2). They emphasized that they mostly acquired expertise in the field of agricultural practices from their families (passed down from generation to generation) while the information provided in the course of training or meetings with advisors have usually been general. Moreover, the respondents stated that the Code as such did not encourage potential readers to read it. Its detailedness and formal and legal language discourage potential readers and that's why farmers mostly base their knowledge on oral instructions which are cursory. Interestingly enough, only one person stated insufficient funds as a reason for noncompliance with the Code's recommendations which they would be required to invest to adjust their production to specific requirements.

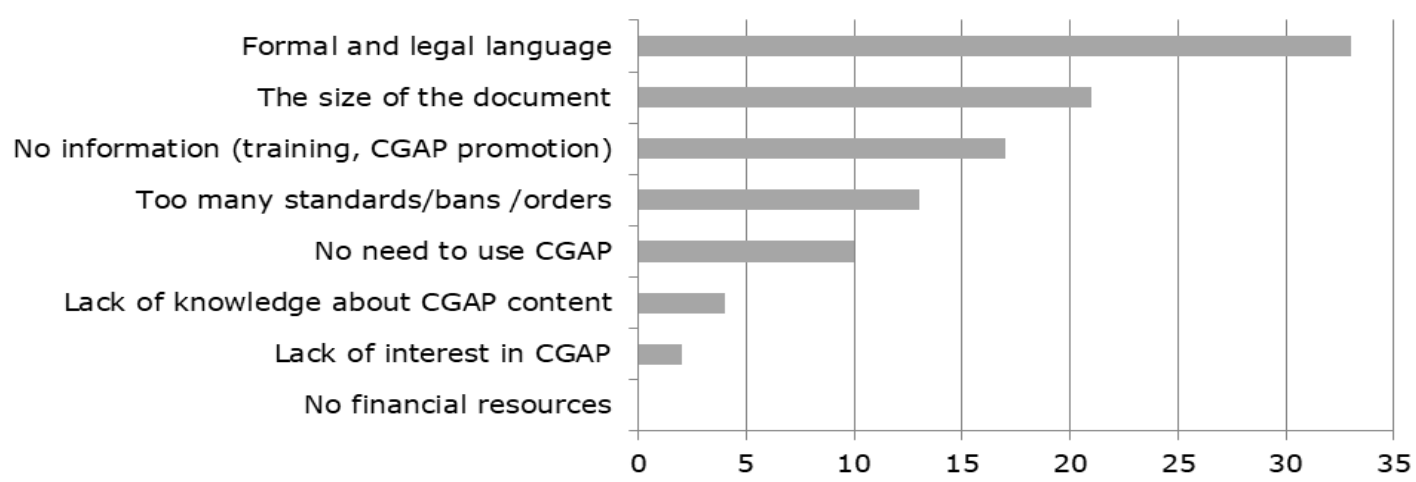

Source: author's calculations based on research

Fig. 2. Reasons of non-compliance with the CGAP's recommendations specified by the respondents (in \%)

Despite a relatively high percentage of the respondents indicating noncompliance or partial compliance with the Code's recommendations on the surveyed farms, the respondents correctly emphasized the need for the Code and its practical application (Figure 3). Over $60 \%$ of the respondents recognized the Code of Good Agricultural Practice as a tool needed for farming, conducive to the protection of the environment that fits in the concept of sustainable development and a model of sustainable agriculture.

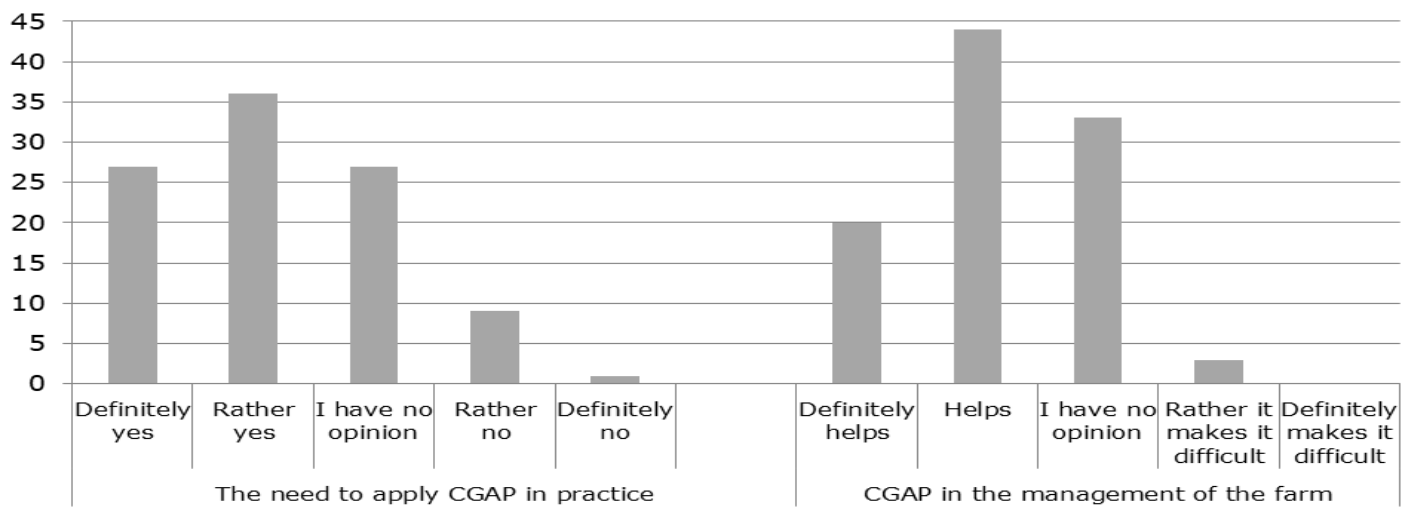

Source: author's calculations based on research

Fig. 3. The respondents' opinions regarding the need for the existence of the CGAP and its impact on farm management (in \%) 
Nearly $30 \%$ of the respondents were unable to make a clear statement regarding the issue. It should be stressed that the group certainly consists of the Code's supporters who, having read the Code and become familiar with its contents, will begin to apply its individual provisions in practice. Similarly inspiring results were obtained when the respondents were enquired whether the Code of Good Agricultural Practice can be treated as an indispensable tool that ensures that the farm is managed properly. The majority of the respondents, i.e. $64 \%$, stated that the guidelines contained in the CGAP were certainly helpful in agricultural production in accordance with the law. However, it should be noted that 12 respondents who stated that they definitely needed to comply with the Code's recommendations in practice, were not clearly convinced that it was correct to follow them in regard of their own farms. It is an inspiring fact that none of the respondents adopted a clearly negative attitude towards the CGAP stating that the implementation of its recommendations in practice would interfere with running the farm.

The survey's main purpose was to become familiar with the respondents' opinions regarding the impact of the practical implementation of the CGAP's recommendations on the functioning of the farms and their immediate environment. Hence, the respondents were asked to indicate noticeable changes resulting from the application of good agricultural practices. The protection of the environment as a whole was correctly recognized as a key answer by the respondents (Figure 4). The purpose of the Code is to promote agricultural activities following the principles of the rational use of the natural environment. The second most frequently chosen answer in the survey was controlling pollution on the farms. Nearly $25 \%$ of the respondents confirmed that compliance with norms regarding, among other things, the use of mineral fertilizers and plant protection agents, storing organic fertilizers, waste management or keeping set grace periods had definitely helped reduce pollution in general on the farms and in the neighbouring area. Based on nearly $13 \%$ of all answers given in the survey, the compliance with the CGAP in practice also contributes to the improvement of the quality of the agricultural production, which in turn leads to the farm's better image vis-a-vis neighbouring entities since the respondents confirmed that the environmental practices applied in farming help improve the farms' image, in that way giving them a chance to improve their competitive edge compared to other farms.

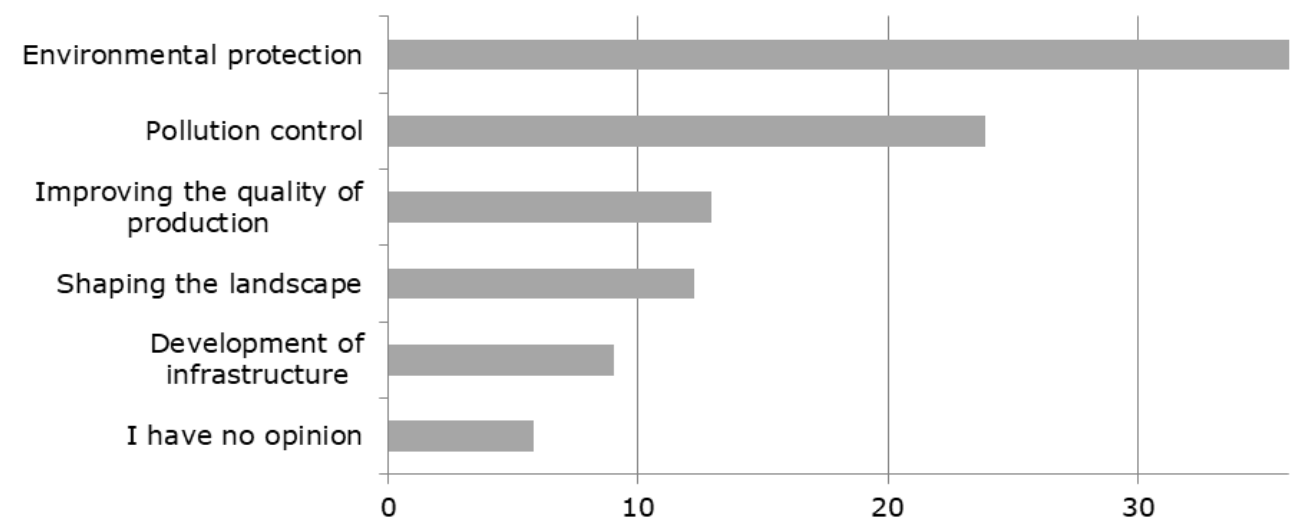

Source: author's calculations based on research

Fig. 4. The impact of the compliance with the CAGP recommendations based on the respondents' opinions (in \%)

\section{Conclusions}

1) Agricultural activities entail the use of the elements of the environment which are indispensable for agricultural production such as soil, water and air. The more intense agricultural use, the 
bigger and more permanent consumption of environmental resources. Therefore, introducing or keeping a balance between agriculture and environment must be a regular and long-term process based on the holistic approach to the farm and applicable legal regulations (Duer, 2017) also provided for in one of the fundamental documents the affect the farmers' attitude towards the environment, i.e. the Code of Good Agricultural Practice. Compliance with the recommendations, instructions and prohibitions provided for in the CGAP result in the farmers' liability for the improvement of the condition and quality of the natural environment and also contribute to the implementation of the assumptions of the concept of sustainable development (including sustainable agriculture), including due to its importance to the management of natural resources.

2) Compliance with good agricultural practices mainly depends on the farmer's expertise, including their awareness as regards the impact of their agricultural activities (especially the adopted agricultural system) on the environment. Compliance with the CGAP rules is voluntary for all farmers who do not benefit from financial assistance granted as part of the Common Agricultural Policy. Thus, compliance with the principles and recommendations of the Code of Good Agricultural Practice is not an obligatory requirement for farmers who are not the beneficiaries of the system of direct payments or other aid programs. Therefore, the need to regularly inform and make the farmers aware of the adverse impact of their agricultural activities on the environment and how to prevent it seems to be crucial, even the more so as over $25 \%$ of the respondents have not come across the concept of the CGAP, have not been familiar with its contents and have not applied its principles in practice.

3) The respondents who declared that they were familiar with the contents of the Code, correctly stressed the need to comply therewith. They were aware of the fact that only compliance with the principles of good agricultural practice would allow them to engage in the activities that are not harmful to the environment and are in line with the concept of sustainable development. Recognizing the environment protection and control of pollution on farms as major benefits stemming from the application of good agricultural practices, the respondents validated the importance of the Code as one of the elements that help implement the concept of sustainable development.

\section{Bibliography}

1. Adamska, H. (2015). Zrownowazony rozwoj obszarow wiejskich na przykladzie Dolnego Slaska (Sustainable development of rural areas on the example of Lower Silesia). Wyd. Uniwersytetu Przyrodniczego we Wroclawiu, Wroclaw.

2. Brown, L., Kene, H., Roodman, D. M. (1995). Swiat w ktorym zyjemy. Trendy ksztaltujace nasza przyszlosc (The world in which we live. Trends shaping our future). Wyd. Ksiazka i Wiedza, Warszawa.

3. Boltromiuk, A. (2006). Przyczyny i skutki wzrostu zainteresowania aspektem srodowiskowym w polityce rolnej UE (The reasons and consequences of increasing interest of cap environmental aspects). Roczniki Naukowe Stowarzyszenia Ekonomistow Rolnictwa i Agrobiznesu, VIII(4), pp. 59-63.

4. Dacko, M., Plonka, A. (2012). Moja Natura (My Nature). Wyd. Starostwo Powiatowe w Nowym Saczu, Nowy Sacz.

5. Dacko, M., Plonka, A. (2017). Idea rozwoju zrownowazonego w opiniach i postawach rolnikow (Idea of sustainable development in the opinions and attitudes of farmers). Roczniki Naukowe Stowarzyszenia Ekonomistow Rolnictwa i Agrobiznesu, XIX(1), pp. 38-43.

6. Duer, I. (2017). Dobra praktyka rolnicza w programach rolnosrodowiskowych (Good agricultural practice in agri-environmental programs). IUNiG, Pulawy. Retrieved from:

http://www.tnz.most.org.pl/dokumenty/publ/ochrona/dobra_praktyka.htm Access: 01.02.2018.

7. Kania, J. (2006). Programy rolno-srodowiskowe i zasady dobrej praktyki rolniczej jako mozliwosc optymalnego gospodarowania i ochrony dolin rzecznych (Agri-environmental programme and good farming practices as opportunities of the best farming system and protection of river-valleys). Infrastruktura $\mathrm{i}$ Ekologia Terenow Wiejskich, 2006/4(1), pp. 74-99. 
8. Kozlowski, S. (2004). Ochrona roznorodnosci biologicznej i georoznorodnosci jako elementu zrownowazonego rozwoju Europy (Protection of biodiversity and geodiversity as an element of the sustainable development of Europe) (in:) Chmielewski T. J., Problemy organizacji i funkcjonowania systemu ostoi siedliskowych Natura 2000 w Polsce (Problems of organization and functioning of Natura 2000 habitat sites in Poland). ZN PAN, Komitet Naukowy Czlowiek i Srodowisko, Warszawa, pp. 13-34.

9. Kraciuk, J. (2004). Propozycja zmian we Wspolnej Polityce Rolnej (Proposed changes in the Common Agricultural Policy). Wspolnoty Europejskie (European communities), 11.

10. Krol, M. A. (2013). Producent rolny jako podmiot korzystajacy ze srodowiska (Agricultural producer as a user of the environment). Wyd. Studia Iuridica Lublinensia, Lublin.

11. OECD (2012). Environmental Outlook to 2050. Consequences of Inaction, OECD Publishing. Retrieved from: http://dx.doi.org/10.1787/9789264122246-en Access: 01.02.2018.

12. Plonka, A. (2017). Wplyw zasad Kodeksu Dobrej Praktyki Rolniczej na poprawe konkurencyjnosci gospodarstw rolnych w opiniach ich wlascicieli (Impact of the Code of Good Agricultural Practice for improving the competitiveness of farms in the opinions of their owners). Marketing i Rynek, 10/2017, pp. 505-516.

13. Rogall, H. (2010). Ekonomia zrownowazonego rozwoju - teoria i praktyka (The economics of sustainable development - theory and practice). Wyd. Zysk i S-ka, Poznan.

14. Sadowski, A. (2007). Zrownowazony rozwoj jako proces spoleczny (Sustainable development as a social process). Ekonomia i Srodowisko, pp. 85-99.

15. Sobocinska, M. (2005). Badania marketingowe przez Internet (Internet Marketing Research) (in:) MazurekLopacinska, K. Badania marketingowe. Teoria i praktyka (Marketing Researches. Theory and practice). Warszawa.

16. Stacewicz, J.,(2001). Cywilizacyjny wymiar rozwoju zrownowazonego (Civilization dimension of sustainable development). Ekonomia i Srodowisko, 1(18), pp. 7-22.

17. Symonides, E. (2008). Ochrona przyrody (Nature protection). Wyd. Uniwersytetu Warszawskiego, Warszawa.

18. Wielewska, I. (2014). Selected environmental aspects of sustainable development in rural areas, Folia Pomeranae Universitatis Technologiae Stetinensis Seria Oeconomica, 314(77)4, p. 159-166.

19. Zegar, J. (2012). Wspolczesne wyzwania rolnictwa (Contemporary agriculture challenges). PWN, Warszawa.

20. Zylicz, T. (2004). Ekonomia srodowiska i zasobow naturalnych (Economics of the environment and natural resources). PWE, Warszawa. 